\title{
Penerapan Model Pembelajaran Problem Based Instruction dengan Studi Kasus untuk Meningkatan Hasil Belajar PKn
}

\author{
Made Sudarmini*
}

SD Negeri 1 Padangbulia

\section{A R T I C L E I N F O}

Article history:

Received 20 May 2019

Received in revised form

10 June 2019

Accepted 30 July 2019

Available online 28

August 2019

Kata Kunci:

Model Pembelajaran

Problem Based

Instruction,Studi

Kasus,Hasil Belajar.

Keywords:

problem-based instruction learning models, case

studies, learning outcomes

\begin{abstract}
A B S T R A K
Sebagian besar siswa di kelas III SD Negeri 1 Padangbulia belum mencapai tingkat ketuntasan belajar yang ditetapkan di sekolah ini yaitu 74. Dari kekurangan yang ada di lapangan tersebut, peneliti mengupayakan sebuah kajian ilmiah dengan melakukan penelitian tidnakan kelas. Tujuan penelitian yang dilakukan ini adalah untuk mengetahui apakah penerapan metode studi kasus dengan model pembelajaran problem based instruction dalam pelaksanaan proses belajar mengajar mampu meningkatkan hasil belajar siswa. Penelitian yang dilakukan dalam dua siklus menggunakan tahapan perencanaan, pelaksanaan, observasi/pengamatan dan refleksi pada setiap siklusnya memfokuskan pencairan datanya menggunakan tes hasil belajar dan melaksanakan analisis dengan analisis deskriptif. Setelah dilakukan refleksi, terjadi peningkatan hasil belajar siswa dari rata-rata nilai 59,32 meningkat menjadi 69,77 rata-rata kelasnya pada siklus I dan pada siklus II meningkat menjadi 83,18. Data tersebut menunjukkan keberhasilan pelaksanaan penelitian sesuai indikator yang dicanangkan. Akhirnya peneliti berkesimpulan bahwa penerapan metode studi kasus dengan model pembelajaran problem based instruction dalam pelaksanaan proses pembelajaran mampu meningkatkan hasil belajar mereka.
\end{abstract}

A B S T R A C T

Most students in grade III to 1 Padangbulia have not reached the level the learning completeness set at this school is 74 . of the shortcomings in the field the researcher sought a scientific study by conducting research class. The purpose of this research is to find out whether the application of the method case study with a learning model based instruction problem in the implementation of the teaching and learning process is able to improve student learning outcomes. research conducted in two cycles using the stages of planning, implementation, observation/observation and reflection in each cycle focuses on disbursing the data using learning outcomes tests and carry out the analysis with descriptive analysis. after reflection, it occurs increasing student learning outcomes from an average value of 59.32 increased to 69.77 on average the class in cycle I and in cycle II increased to 83.18. the data shows the successful implementation of the research according to the indicators proclaimed. finally, the researcher concluded that the application of case study methods to problem learning models based instruction in the implementation of the learning process can improve learning outcomes. 


\section{Pendahuluan}

Pendidikan yang diharapkan agar guru betul melakukan pembelajaran dengan baik,mau membuat perencanaan yang memadai,tepat dalam melaksanakannya,mampu menilai, mengevaluasi,serta menggunakan hasil evaluasi untuk tindak lanjut secara tepat.

Pelajaran PKN merupakan mata pelajaran yang pengajarannya dititikberatkan pada pembentukan karakter.Dengan demikian, mata pelajaran PKN bertujuan agar peserta didik memiliki karakter yang berahlak mulia.

Kurikulum tingkat satuan pendidikan (KTSP) menuntut guru agar menggunakan paradigma baru dalam pembelajaran yaitu: Siswa aktif guru aktif,siswa menemukan, siswa berusaha menyelesaikan permasalahannya di dalam kelompok, siswa mengkontruksikan sendiri pengetahuannya (Suparni, 2016).

Kondisi yang diharapkan dipihak guru adalah mampu membelajarkan peserta didik semaksimal mungkin agar mereka giat melakukan, giat bekerja, giat berdiskusi, giat bertanya, giat berargumentasi dan giat dalam memahami apa yang diajar. Kondisi tersebut apabila mau dicapai tentu guru harus giat melakukan pembelajaran yang lebih menantang, lebih memotivasi, lebih membuat siswa giat berargumentasi. Kondisi tersebut tidak serta merta akan bisa terjadi tanpa kemampuan guru untuk melaksanakannya.

Proses pembelajaran di kelas akan sangat efektif apabila guru melaksanakannya dengan memahami peran, fungsi dan kegunaan mata pelajaran yang diajarnya. Selain pemahaman hal-hal tersebut keefektipan itu juga ditentukan oleh kemampuan guru untuk merubah model pengajaran menjadi model pembelajaran yang lebih sesuai pada masa sekarang.

Peran mata pelajaran PKN adalah untuk pengembangan intelektual, sosial dan emosional siswa serta berperan sebagai kunci penentu menuju keberhasilan dalam mempelajari suatu bidang tertentu. Fungsi mata pelajaran PKN adalah sebagai suatu bidang kajian untuk mempersiapkan siswa mampu merefleksikan pengalamannya sendiri dan pengalaman orang lain, mengungkapkan gagasan-gagasan dan perasaan serta memahami beragam nuansa makna, sedang kegunaannya adalah untuk membantu siswa mengenal dirinya, budayanya, budaya orang lain, mengemukakan gagasan dan perasaan, berpartisipasi dalam masyarakat, membuat keputusan yang bertanggung jawab pada tingkat pribadi, sosial, menemukan serta menggunakan kemampuan analitic dan imajinatif yang ada dalam dirinya. Disamping mengetahui peran, fungsi dan kegunaan mata pelajaran, sebagai seorang guru juga diperlukan untuk mampu menerapkan beberapa metode ajar sehingga paradigma pengajaran dapat dirubah menjadi paradigma pembelajaran.

Kelemahan-kelemahan yang dilakukan guru selama proses pembelajaran yang menyebabkan rendahnya hasil belajar siswa tidak sepenuhnya disebabkan oleh faktor luar seperti kesibukan guru, keadaan rumah tangga, lingkungan dan lain-lain. Kelemahan-kelemahan yang ada tentu banyak pula dipengaruhi oleh faktor dari dalam diri guru itu sendiri seperti kemauan menyiapkan bahan yang lebih baik, termasuk kemauan guru itu sendiri untuk menerapkan metode-metode ajar yang telah didapat di bangku kuliah. Selain itu guru juga kurang mampu untuk dapat mengembangkan keterampilan mengajar yang dapat menarik perhatian siswa dan merangsang siswa untuk belajar. Keterampilan yang mesti dikuasai guru dalam melaksanakan pembelajaran ada 7, yaitu: 1) keterampilan bertanya, 2) keterampilan memberi penguatan, 3) keterampilan mengadakan variasi, 4) keterampilan menjelaskan, 5) keterampilan membuka dan menutup pelajaran, 6) keterampilan membimbing diskusi, 7) keterampilan mengelola kelas. Keterampilan-keterampilan ini berhubung dengan kemampuan guru untuk menguasai dasar-dasar pengetahuan yang berhubungan dengan persiapan dan pelaksanaan proses pembelajaran yang akan memberikan dukungan terhadap cara berpikir siswa yang kreatif dan imajinatif. Hal inilah yang menunjukkan profesionalisme guru (I G. A. K. Wardani dan Siti Julaeha, Modul IDIK 4307: 1-30).

Berbagai upaya telah dilakukan oleh pemerintah dalam meningkatkan mutu pendidikan di Indonesia, namun sampai saat ini belum memperoleh hasil yang optimal. Fenomena ini dapat dilihat dari indikator hasil belajar, antara lain dari capaian Nilai Ujian Nasional secara rata-rata siswa masih tergolong rendah.Berkembangnya pendidikan dewasa ini, juga dibarengi dengan berkembangnya metode-metode dan gaya pengajaran sehingga dapat meningkatkan mutu pendidikan. Metode dan gaya pengajaran merupakan alat yang sangat mujarab untuk mencapai tujuan pendidikan.Walaupun begitu banyak metode dan gaya mengajar tanpa partisipasi dari insan pendidik maka pendidikan itu tidak akan ada artinya.

Penggunaan model-model pembelajaran termasuk salah satunya adalah model pembelajaran Kuantum juga merupakan hal yang sangat penting dalam upaya memajukan suatu bidang tertentu. Model sangat berkaitan dengan teori. Model merupakan suatu analog konseptual yang digunakan untuk menyarankan bagaimana meneruskan penelitian empiris sebaiknya tentang suatu masalah. Jadi model merupakan suatu struktur konseptual yang telah berhasil dikembangkan dalam suatu bidang dan sekarang diterapkan, terutama untuk membimbing penelitian dan berpikir dalam bidang lain, biasanya 
dalam bidang yang belum begitu berkembang (Mark 1976 dalam Ratna Wilis Dahar, 1989: 5) dalam Marhaeni 2014: 2.

Kedua cuplikan di atas menunjukkan betapa pentingnya model untuk diterapkan dalam mencapai suatu keberhasilan, begitu pula terhadap kegunaan model-model pembelajaran.

Satu alternatif pembelajaran yang dapat dilakukan agar siswa lebih aktif dalam pembelajaran dan dapat mengkonstruksi pengetahuannya secara mandiri adalah dengan menerapkan model Problem Based Instruction (PBI) atau pengajaran berdasarkan masalah. Ibrahim dan Nur (2000), berpendapat bahwa pengajaran berdasarkan masalah tidak dirancang untuk membantu peneliti memberikan informasi sebanyak-banyaknya kepada siswa. Pengajaran berdasarkan masalah dikembangkan untuk membantu siswa mengembangkan kemampuan berpikir, pemecahan masalah, keterampilan intelektual, belajar berbagai peran orang dewasa melalui pelibatan mereka dalam pengalaman nyata atau simulasi serta menjadi pebelajar yang otonom dan mandiri. Fase-fase model PBI menurut Ibrahim (2005) meliputi: 1) orientasi siswa pada masalah, 2) mengorganisasikan siswa untuk belajar, 3) membimbing penyelidikan individual maupun kelompok, 4) mengembangkan dan menyajikan hasil karya, dan 5) menganalisis dan mengevaluasi proses pemecahan masalah (Katon, 2016).

Pembelajaran Problem Based Instruction (PBI). " Metode pembelajaran PBI adalah model pembelajaran yang berlandaskan paham konstruktivisme yang mengakomodasi keterlibatan peserta didik dalam belajar dan pemecahan masalah otentik. Menurut Aisyah (2003) model PBI adalah salah satu model pembelajaran yang dapat merangsang aktivitas dan nalar peserta didik, sehingga kreatifitas peserta didik dapat berkembang secara optimal" (Yulidatullah, 2018).

Model Problem Based Instruction (PBI) diperkuat oleh teori Bruner (1915) yang menyatakan bahwa "Berusaha sendiri untuk mencari pemecahan masalah serta pengetahuan yang menyertainya, menghasilkan pengetahuan yang benar-benar bermakna". Suatu pernyataan logis, karena dengan mencari solusi pemecahan masalah secara mandiri akan memberi suatu pengalaman nyata, dengan pengalaman tersebut dapat digunakan pula memecahkan masalah-masalah serupa, karena pengalaman ini memberi makna tersendiri bagi siswa (Muttaqien, 2017).

Keunggulan model Problem Based Instruction, yaitu menekankan pada makna bukan fakta, meningkatkan pengarahan diri, pemahaman yang lebih tinggi dan keterampilan yang lebih baik, mengembangkan keterampilan interpersonal dan tim, adanya sikap motivasi pada diri sendiri, dan hubungan yang baik antara siswa dengan guru, dan meningkatkan pembelajaran (Fakhriyah, 2016).

Menurut Dimyati dan Mudjiono (1999), hasil belajar merupakan hal yang dapat dipandang dari dua sisi yaitu sisi siswa dan dari sisi guru. Dari sisi siswa, hasil belajar merupakan tingkat perkembangan mental yang lebih baik bila dibandingkan pada saat sebelum belajar. Howard Kingsley (Nana Sudjana, 2005: 85) membagi 3 macam hasil belajar: 1) Keterampilan dan kebiasaan; 2) Pengetahuan dan pengertian; dan 3) Sikap dan cita-cita. Pendapat dari Horward Kingsley ini menunjukkan hasil perubahan dari semua proses belajar. Hasil belajar ini akan melekat terus pada diri siswa karena sudah menjadi bagian dalam kehidupan siswa tersebut. Berdasarkan pengertian di atas maka dapat disintesiskan bahwa hasil belajar adalah suatu penilaian akhir dari proses dan pengenalan yang telah dilakukan berulangulang. Serta akan tersimpan dalam jangka waktu lama atau bahkan tidak akan hilang selama-lamanya karena hasil belajar turut serta dalam membentuk pribadi individu yang selalu ingin mencapai hasil yang lebih baik lagi sehingga akan mengubah cara berpikir serta menghasilkan perilaku kerja yang lebih baik (Sulastri, 2015).

Sudijono (2012, p.32) mengungkapkan hasil belajar merupakan sebuah tindakan evaluasi yang dapat mengungkap aspek proses berpikir (cognitive domain) juga dapat mengungkap aspek kejiwaan lainnya, yaitu aspek nilai atau sikap (affective domain) dan aspek keterampilan (psychomotor domain) yang melekat pada diri setiap individu peserta didik. Ini artinya melalui hasil belajar dapat terungkap secara holistik penggambaran pencapaian siswa setelah melalui pembelajaran (Tri, 2016).

Berdasarkan semua uraian di atas dapat diketahui hal-hal yang perlu dalam upaya meningkatkan hasil belajar siswa seperti penguasaan metode-metode ajar; penguasaan model-model pembelajaran; penguasaan teori-teori belajar; penguasaan teknik-teknik tertentu; penguasaan peran, fungsi serta kegunaan mata pelajaran. Apabila guru menguasai dan mengerti tentang hal-hal tersebut dapat diyakini bahwa hasil belajar peserta didik pada mata pelajaran PKN tidak akan rendah. Namun, kenyataannya hasil belajar siswa kelas III di semester I tahun Pelajaran 2018/2019 baru mencapai rata-rata 57,62 dari KKM yang ditetapkan adalah 74 namun dari 22 orang siswa baru 8 orang siswa yang memenuhi standar.

Melihat kesenjangan antara harapan-harapan yang telah disampaikan dengan kenyataan lapangan sangat jauh berbeda, dalam upaya memperbaiki mutu pendidikan utamanya pada mata pelajaran PKN, sangat perlu kiranya dilakukan perbaikan cara pembelajaran. Salah satunya adalah perbaikan pembelajaran dengan menggunakan model pembelajaran Problem Based Instruction Dengan Studi Kasus Oleh karenanya penelitian ini sangat penting untuk dilaksanakan. 


\section{Metode}

Jenis penelitian yang dilakukan adalah penelitian pendidikan kelas. Lokasi penelitian dilaksanakan di SN No 1 Padangbulia. Penilitian ini akan dilaksanakan pada semester I tahun 2018/2019 dari bulan Juli sampai Oktober tahun 2018. Rancangan penelitian digunakan sebagai dasar atau patokan dalam melakukan penelitian agar pelaksanaannya dapat berjalan secara benar, baik, dan lancar. Rancangan penelitian memberikan gambaran tentang apa yang harus dilakukan peneliti dalam sebuah penelitian.

Prosedur:

Agar penelitian tidak salah dan lebih ilmiah maka prosedur yang dilakukan tidaklah mengikuti alur yang dikehendaki oleh peneliti sendiri. Alur yang dilakukan tanpa melihat pendapat ahli menyatakan bahwa seolah- olah peneliti sendiri sudah ahli,padahal peneliti baru mencoba menyelesaikan sebuah Penelitian Tindakan Kelas untuk pertamakali. Jadi, agar tidak ada kesalahan maka peneliti mengikuti alur gambar yang telah dipilih berdasar pendapat ahli sebagai prosedur pelaksanaannya di lapangan. Untuk itu dimulai dengan

Tindakan daur I dilakukan definisi masalah dilanjutkan dengan pelaksanaan di lapangan, dirumuskan hipotesisnya, dikembangkan hipotesis tersebut, diimplementasikan, dievauasi dari hasil yang didapat dan evaluasi diterapkan. Langkah-langkah pada daur II atau siklus II sama dengan yang di siklus I yaitu dimulai dengan adanya suatu permasalahan yang baru, didefinisikan masalahnya, dibuat hipotesisnya direvisi, selanjutnya dilakukan implementasi di lapangan, dievaluasi, kemudian hasil yang didapat merupakan penerapan baru apabila masih adalah masalah

Setelah mengetahui bagaimana hasil dan efeknya, dibuat lagi perencanaan untuk tindakan selanjutnya.Demikian beranjut sampai menemukan hasil yang sesuai tujuan yang direncanakan..

\section{Hasil dan Pembahasan}

\section{Refleksi Siklus I}

Refleksi merupakan kajian secara menyeluruh tindakan yang dilakukan berdasar data yang telah terkumpul,kemudian dilakukan evaluasi guna penyempurnaan tindakan. Refleksi menyangkut analisis, sintesis, dan penilaian terhadap hasil pengamatan atau tindakan yang dilakukan Elliot, 1991 (dalam Sukidin, Basrowi, Suranto, 2002: 52) dalam Marhaeni 2014:25.

Sesuai pendapat ahli di atas, maka dalam refleksi ini disampaikan analisis,sintesis, dan penilaian seperti berikut :

a. Refleksi yang dapat disajikan adalah dari 22 orang anak yang diteliti baru 12 anak yang berkembang sesuai indikator. Itu artinya 54,55 \% anak yang mengalami peningkatan kemampuan pada siklus ini. Ada $10(45,45 \%)$ yang memperoleh penilaian di bawah KKM yang artinya bahwa mereka belum berhasil.

b. Upaya yang dilakukan guru untuk mendorong kemampuan anak sudah membuahkan hasil jika dibandingkan dengan data awal, yang menjadi landasan berpikir peneliti adalah segala sesuatu yang dipelajari membutuhkan waktu untuk mencapai tingkat yang diinginkan. Namun, untuk lebih mempercepat tercapainya tujuan tersebut upaya memvariasikan media dan permainan tetap dilakukan agar motivasi dan minat anak tetap berkembang sesuai dengan apa yang diharapkan. Melihat presentase ketuntasan belajar tersebut maka penelitian ini dinyatakan belum berhasil karena melihat kreteria ketuntasan belajar yang telah ditetapkan sebesar $85 \%$, sedangkan prosentase hasil ketuntasan belajar secara klasikal baru mencapai 54,55 \%. Sedangkan prosentase hasil belajar berdasarkan daya serap maka penelitian ini dinyatakan belum berhasil karena daya serap yang ditetapkan sebesar $80 \%$, sedangkan perolehan hasil belajar berdasarkan daya serap baru tercapai 69,77\%.Merujuk dari hasil tersebut, maka penelitian akan tetap dilanjutkan pada pelaksanaan siklus II. Dari pengamatan peneliti selama melakukan tindakan untuk 3 kali pertemuan,bahwa hampir sebagian siswa sudah mampu memahami dan mengikuti pembelajaran yang tergolong masih baru untuk anak SD yaitu pembelajaran yang menggunakan metode Studi Kasus dalam pelaksanaan Problem Based Instructional. Hal ini dapat didukung oleh hasil persentase ketuntasan belajar siswa yaitu 45,45\% di mana ada 10 siswa yang belum mencapai KKM. Selain itu dapat pula didukung oleh hasil observasi tentang keaktifan dan sikap siswa.

\section{Refleksi Siklus II}

Melihat presentase ketuntasan belajar tersebut maka penelitian ini dinyatakan sudah berhasil karena melihat kreteria ketuntasan belajar yang telah ditetapkan sebesar $85 \%$, sedangkan perolehan hasil belajar dari ketuntasan belajar secara klasikal tercapai 90,91\%. Begitu juga melihat prosentase daya serap tersebut maka penelitian ini dinyatakan sudah berhasil, karena hasil belajar berupa daya serap yang 
ditetapkan sebesar 80\%,telah tercapai daya serap sebesar 83,18\%. Merujuk dari hal tersebut, maka penelitian ini akan dihentikan dan akan dibahas dalam pembahasan serta akan dilanjutkan dengan memberikan simpulan.

Berdasarkan analisis data hasil belajar pada siklus II, selanjutnya diadakan analisis hasil observasi terhadap hasil belajar siswa ataupun terhadap keseluruhan proses pembelajaran. Adapun hasil analisis tersebut adalah sebagai berikut: 1 . Selama proses pembelajaran siklus II, semakin banyak siswa yang menunjukkan peningkatan keaktifan belajarnya, 2. Waktu dalam pembelajaran dapat digunakan dengan efektif, tidak seperti pada pelaksanaan siklus I. Hal ini dikarenakan siswa baru pertama kali mengalami proses pembelajaran seperti ini, dan 3. Selama pelaksanaan pembelajaran siklus II, ketrampilan peneliti untuk melaksanakan pembelajaran juga sudah mengalami penin gkatan. Hal ini karena peneliti benar-benar sudah melakukan perbaikan diri sesuai refleksi dari siklus I.

Melihat refleksi siklus II di atas, dapat dikatakan bahwa penelitian telah berhasil karena kreteria keberhasilan penelitian yang ditetapkan sudah terpenuhi. Kendala-kendala yang ditemui pada siklus I, sudah dapat diatasi pada siklus II. Dengan demikian penerapanModel pembelajaran Problem Based Instructional dengan menggunakan metode Studi Kasus dapat meningkatkan hasil balajar PKN siswa kelas III SD Negeri 1 Padangbulia semester I (ganjil) tahun pelajaran 2017/2018. Oleh karena itu, maka dapat diputuskan bahwa penelitian dihentikan pada siklus II.

\section{Rekap Hasil Penelitian}

Secara individual ataupun secara klasikal, pada siklus I diperoleh hasil belajar siswa berupa ketuntasan belajar secara klasikal sebesar 54,55\% dengan tingkat hasil belajar belum begitu baik. Pada siklus II, hasil belajar siswa meningkat menjadi 90,91\% dengan tingkat hasil belajar yang berada pada kategori sangat baik. Peningkatan hasil belajar PKN siswa kelas II dari siklus I ke siklus II juga terlihat dari peningkatan daya serap belajar siswa, yaitu dari $69 \%$ pada siklus I menjadi $83 \%$ pada siklus II. Ketuntasan belajar siswa dan daya serap siswa pada siklus II sudah memenuhi kreteria yang ditetapkan pada indikator keberhasilan penelitian yaitu: minimal $>85 \%$ untuk ketuntasan belajar, dan $>80 \%$ untuk daya serap.

Dalam menyampaikan hasil penelitian dan pembahasan, perlu menyajikan uraian masing-masing siklus dengan data lengkap mulai dari perencanaan, pelaksanaan, pengamatan/observasi dan refleksi yang berise penjelasan tentang aspek keberhasilan dan kelemahan yang terjadi. Perlu ditambahkan hal yang mendasar, yaitu hasil perencanaan (kemajuan) pada diri siswa, lingkungan, guru, motivasi dan aktivitas belajar.

Suharsimi Arikunto, Suhardjono, Supardi (2006: 83) menyatakan bahwa, dalam menyampaikan hasil penelitian dan pembahasan, perlu menyajikan uraian masing-masing siklus dengan data lengkap mulai dari perencanaan, pelaksanaan, pengamatan dan refleksi yang berisi penjelasan tentang aspek keberhasilan dan kelemahan yang terjadi. Juga disampaikan kemajua) pada diri siswa, lingkungan, guru, motivasi dan aktivits belajar, situasi kelas dan hasil belajar, kemukakan grafik dan tabel hasil analisis data yang menunjukkan perubahan yang terjadi disertai pembahasan secara sistimatis dan jelas.

Setelah dilaksanakan / diadakan penelitian yang berlangsung dalam 2 siklus, terjadi peningkatan hasil belajar PKN siswa kelas III SD Negeri 1 Padangbulia semester I (ganjil) tahun pelajaran 2017/2018 setelah penerapan model pembelajaran Problem Based Instructional dengan Studi Kasus.

Berdasarkan penjelasan di atas dapat dilihat bahwa perolehan hasil belajar siswa berupa ketuntasan secara klasikal pada observasi awal sebesar 36,36\% dengan tingkat hasil belajar kurang,karenabelum semua siswa aktif dalam mengikuti proses pembelajaran. Pada siklus I, hasil belajar siswa meningkat menjadi 54,55\% dengan tingkat hasil belajar kurang baik, kemudian pada siklus II, hasil belajar siswa semakin meningkat menjadi 90,91\% dengan tingkat hasil belajar berada pada kategori sangat baik, Demikian pula daya serap belajar siswa juga tampak mengalami peningkatan dari 59,32 \%, pada observasi awal, menjadi 69,77 \% pada siklus I dengan tingkat hasil belajar daya serap yang berada pada kategori cukup pada siklus I dan $83,18 \%$ pada siklus II dengan tingkat hasil belajar daya serap yang berada pada kategori baik.

Peningkatan hasil belajar PKN siswa kelas III seperti di atas menunjukkan bahwa dengan belajar PKN melalui penerapan model pembelajaran Problem Based Instructional dengan Studi Kasus, materi yang dipelajari siswa benar-benar dapat dipahami dan melekat dalam ingatan siswa. Hal ini sesuai dengan pendapat Shackuford dan Henak dalam Soekartawi ( 1995: 42 ), berpendapat bahwa cara pengajaran yang efektif akan terbentuk jika pengajarnya juga bertindak efektif. Sebab pengajar bertindak sebagai manajer yang harus mengambil keputusan untuk aktivitas yang dilakukan agar berjalan secara efektif.Setiap pengajar atau guru mempunyai / memiliki keahlian di dala memilih model dan metode pengajaran. Metode pengajaran yang dipakai sebaiknya sesuai dengan bahan ajar atau materi yang diberikan. Karena metode pengajaran sangat menentukan efektivitas pembelajaran.Penggunaan metode yang tepat 
pengajaran mendorong siswa lebih cepat dalam menyerap / menerima informasi yang disampaikan oleh guru, siswa akan lebih termotivasi untuk belajar. Berdasarkan penelitian Colletti dalam Soekartawi (1995: 43 - 44), diungkapkan bahwa penggunaan metode pengajaran yang sesuai dengan didukung sumber belajar yang tepat akan lebih efektif dibandingkan dengan penggunaan model pembelajaran lainnya.

Dalam hal ini, kegiatan refleksi pada tahap akhir pembelajaran,siswa mengakui bahwa setelah belajar dengan seringnya diberikan tugas-tugas atau latihan-latihan seperti ini menjadikan siswa lebih tertarik untuk belajar, selain itu siswa sangat mengharapkan banyak variasi dalam pembelajaran. Dengan kata lain, siswa menuntut gurunya untuk selalu menciptakan pembelajaran yang lebih menarik lagi.

Peningkatan hasil belajar PKN siswa kelas III di atas juga disebabkan oleh semakin meningkatnya keaktifan siswa disetiap siklus. Adapun peningkatan keaktifan siswa, menunjukkan bahwa siswa betulbetul berpartisipasi aktif dalam pembelajaran. Sesuai dengan pendapat yang dikemukakan Edgar Dale (dalam Sadirman, dkk, 2003:7:8) dalam klasifikasi pengalaman menurut tingkat dari yang paling konkrit ke yang paling abstrak dimana partisipasi, observasi dan pengalaman langsung memberikan pengaruh yang sangat besar terhadap pengalaman belajar yang diterima siswa.

Peningkatan hasil belajar PKN siswa kelas III juga disebabkan karena dengan belajar melalui penerapan model pembelajaran Problem Based Instructional dengan Studi Kasus menjadi lebih tertarik, senang dan siswa tidak merasa bosan dalam belajar PKN. Sesuai dengan pendapat Turmudi (dalam Darsono,2010), yaitu bahwa pembelajaran dengan menerapkan metode yang tepat telah mengubah pandangan siswa, yang awalnya sangat membosankan menjadi sangat menyenangkan atau sangat menarik, sehingga kemauan siswa untuk belajar khususnya mempelajari pelajaran PKN menjadi lebih semangat / semakin besar.

Berdasarkan uraian di atas, penelitian ini secara umum telah mampu menjawab rumusan masalah serta dapat menentukan kebenaran dari hipotesis yang sudah ditentukan sebelumnya. Hal ini berarti bahwa penelitian ini telah mampu memecahkan masalah rendahnya hasil belajar PKN siswa klelas III SD Negeri 1 Padangbulia semester I ( ganjil) tahun pelajara 2017/2018. Pada akhir penelitian semua kreteria keberhasilan penelitian telah terpenuhi. Dengan kata lain, penelitian yang telah dilaksanakan telah berhasil

\section{Simpulan Dan Saran}

Berdasarkan hasil penelitian dan pembahasan yang telah diuraikan pada Bab IV, dapat disimpulkan bahwa Penerapan Model Pembelajaran Problem Based Instructional dengan Studi Kasus untuk meningkatkan hasil belajar PKN siswa kelas III SD Negeri 1 Padangbulia semester I (ganjil) Tahun Pelajaran 2017/2018"

Penelitian tindakan kelas yang dilakukan ini membawa pembuktian tentang keberhasilan pelaksanaan tindakan yang dilakukan menggunakan penerapan-penerapan metode Studi Kasus dan model pembelajaran Problem Based Instruction. Pemicu rendahnya hasil belajar ada pada faktor model/metode yang digunakan guru dalam proses pembelajaran.Untuk itu penggunaan model/ metode yang sifatnya konstruktivis sangat diperlukan. Dalam hal ini peneliti menerapkan model pembelajaran Problem Based Instruction dan metode Studi Kasus sebagai solusi untuk memecahkan permasalahan yang ada.

Dari hasil refleksiyang telah disampaikan di Bab IV dan dengan melihat semua data yang telah dipaparkan, dapat disampaikan bahwa pencapaian tujuan penelitian di atas dapat dibuktikan dengan argumentasi sebagai berikut. Dari data awal ada 14 siswa mendapat nilai dibawah KKM dan pada siklus I menurun menjadi 10 siswa dan siklus II hanya 2 siswa mendapat nilai di bawah KKM. Nilai rata-rata awal 59,32 naik menjadi 69,77 pada siklus I dan pada siklus II naik menjadi 83,18. Dari data awal siswa yang tuntas hanya 8 orang sedangkan pada siklus I menjadi lebih banyak yaitu 12 siswa dan pada siklus II menjadi cukup banyak yaitu 20 siswa.

Paparan di atas membuktikan bahwa model pembelajaran Problem Based Instruction dan metode Studi Kasus dapat memberi jawaban sesuai tujuan penelitian ini. Semua ini dapat dicapai karena model pembelajaran Problem Based Instruction dan metode Studi Kasus sangat efektif diterapkan dalam proses pembelajaran yang mengakibatkan siswa aktif, antusias dan dapat memahami materi yang diajarkan sehingga hasil belajar siswa menjadi meningkat.

Saran yang dapat disampaikan sehubungan dengan keberhasilan tindakan yang diberikan maka saran-saran sebagai berikut:

1. Bagi guru kelas, apabila mau melaksanakan proses pembelajaran penggunaan model/metode yang telah diterapkan ini semestinya menjadi pilihan dari beberapa model/metode yang ada mengingat model/metode ini telah terbukti dapat meningkatkan hasil belajar siswa. 
2. Bagi peneliti lain, walaupun penelitian ini sudah dapat membuktikan efek utama dari model pembelajaran Problem Based Instruction dan metode Studi Kasus dalam meningkatkan hasil belajar, sudah pasti dalam penelitian ini masih ada hal-hal yang belum sempurna dilakukan, oleh karenanya disarankan kepada peneliti lain yang berminat meneliti topik yang sama untuk meneliti bagian-bagian yang tidak sempat diteliti.

3. Bagi Pengawas Sekolah memiliki fungsi utama membina bawahannya, khususnya bagi guru-guru dalam rangka meningkatkan kualitas pembelajaran. Pengawas Sekolah perlu melakukan monitoring secara berkesinambungan tentang kegiatan pembelajaran yang telah dilakukan guru dan membina secara maksimal proses pembelajaran yang dilaksanakan oleh guru

\section{Daftar Rujukan}

Arikunto, Suharsimi. 1995. Dasar-Dasar Evaluasi Pendidikan. Jakarta: BumiAksara.

Arikunto, Suharsimi; Suhardjono; Supardi. 2006. Penelitian Tindakan Kelas. Jakarta: PT Bumi Aksara.

Djamarah, Syaful Bahri. 2002. Prestasi Belajar dan Kompetensi Guru. Surabaya: Usaha Nasional.

Hamalik, Oemar. 2002. Psikologi Belajar dan Mengajar. Bandung: Sinar Baru.

Fakhriyah, Fina (2016). Pengaruh Model Problem Based Instruction Dalam Mengembangkan Kemampuan Berpikir Kritis Siswa Sekolah Dasar . Jurnal Konseling GUSJIGANG Vol. 2 No. 1 (Januari-Juni 2016) Print ISSN 2460-1187, Online ISSN 2503-281X

Kardi, Soeparman dan Mohamad Nur. 2000. Pengajaran Langsung. ProgramPascasarjana UNESA: University Press.

Katon ,Sri (2016). Penerapan Model Problem Based Instruction (Pbi) Untuk Meningkatkan Hasil Belajar Matematika Siswa Kelas Viii E Smp Negeri 9 Palu Pada Bahasan Keliling Dan Luas Daerah Lingkaran . Jurnal Pendidikan Matematika, Vol. 5, No. 3, Desember 2016

Muttaqien ,Muhammad (2017). Penerapan Model Problem Based Instructrion Terhadap Kemampuan Berpikir Kritis Pada Materi Pemanasan Global . Jurnal Pendidikan Biologi, Tahun 2017

Nur, Mohamad et al. 2001. Teori Belajar. Surabaya: University Press.

Nurman, Muhammad, 2006. Pengaruh Penggunaan Metode Pembelajaran Problem Based Instruction dan Expositori terhadap SIkap Politik Berdemokrasi dan Prestasi Belajar Siswa pada Pembelajaran PPKn di SMA (Tesis). Singaraja. Institut Keguruan dan Ilmu Pendidikan Negeri Singaraja, Program Pascasarjana.

Oemar Hamalik. 2003. Proses Belajar Mengajar. Bumi Aksara: Jakarta.

Purwanto, Ngalim. 1997. Psikologi Pendidikan. Bandung: Rosdakarya.

Sardiman, A.M. 1988. Interaksi dan Motivasi Belajar-Mengajar Pedoman bagi Guru dan Calon Guru.Jakarta: Rajawali Pers.

Slameto. 2003. Belajar dan Faktor-faktor yang Mempengaruhinya. Jakarta: Rineka Cipta..

Suharsimi, A. 2003. Dasar-dasar Evaluasi. Jakarta: Bumi Aksara.

Sulastri (2015). Meningkatkan Hasil Belajar Siswa Melalui Strategi Pembelajaran Berbasis Masalah Pada Mata Pelajaran IPS di Kelas V SDN 2 Limbo Makmur Kecamatan Bumi Raya . Jurnal Kreatif Tadulako Online Vol. 3 No. 1 ISSN 2354-614X

Sumadi Suryabrata. 1998. Pengembangan Alat Ukur Psikologis. Dirjen Dikti Depdiknas.

Suryabrata, Sumadi. 2000. Pengembangan Alat Ukur Psikologis. Yogyakarta: Penerbit Andi. 
Tri ,Budi (2016). Faktor-Faktor Yang Mempengaruhi Hasil Belajar Siswa Pada Pembelajaran Praktik Kelistrikan Otomotif Smk Di Kota Yogyakarta . Jurnal Pendidikan Vokasi Volume 6, No 1, Februari $2016(111-120)$

Wardani, I. G. A. K Siti Julaeha. Modul IDIK 4307. Pemantapan Kemampuan Mengajar. Jakarta: Universitas Terbuka.

Wina Sanjaya. 2006. Strategi Pembelajaran Berorientasi Standar Proses Pendidikan. Kencana Prenada Media: Jakarta.

Yohanes Surya. 2004. Fisika untuk Semua. PT. Bina Sumber Daya MIPA: Jakarta

Yulidatullah (2018). Penggunaan Metode Problem Based Instruction (pbi) Untuk Meningkatkan Hasil Belajar dan Motivasi Siswa Pada Materi Pengukuran Nilai Resistor Kelas X Di SMK Negeri 1 Darul Kamal Aceh Besar . Jurnal Ilmiah Pendidikan Teknik Elektro, Vol.2, No.1, Februari 2018 